\title{
Peptide Sequence of Pili Subunit Protein 49.8 kDa Shigella flexneri as Antigenic Epitope for Shigellosis Vaccine Development
}

\author{
(D) Khoirul ANAM1,2*, (D) Agustina Tri ENDHARTI ${ }^{3}$, (D) Sri POERANTO ${ }^{3}$, (D) Sumarno Reto PRAWIRO4 \\ 1 Universitas Brawijaya, Faculty of Medicine, Doctoral Program in Medical Science, Malang, Indonesia \\ 2Institute of Technology and Health Science of Wiyata Husada Samarinda, Medical Laboratory Technology Study Program, Samarinda, Indonesia \\ 3 Universitas Brawijaya, Faculty of Medicine, Department of Parasitology, Malang, Indonesia \\ «Universitas Brawijaya, Faculty of Medicine, Department of Clinical Microbiology, Malang, Indonesia
}

\begin{abstract}
Objectives: This study investigates the amino acid sequence and identifies antigenic epitopes of 49.8 kilodalton (kDa) pili protein Shigella flexneri, which will be used as candidates for the shigellosis vaccine.

Materials and Methods: Our study is a prospectively descriptive laboratory. We used bacterial isolate of S. flexneri pili isolation was performed using a pili cutter and sodium dodecyl-sulfate polyacrylamide gel electrophoresis. The amino acid sequences were analyzed using liquid chromatography dual mass spectrometry (LC-MS/MS) method in the proteomic laboratory. The target epitope antigenicity analysis was tested using Kolaskar and Tongaonkar Antigenicity software. The Bepired Linear Epitope Prediction software is used for epitope mapping. PymOL software was used for the visualization of proteins and molecular docking. Peptides and antibodies were applied to hemagglutination test and immune response was tested using the dot blot method.

Results: LC-MS/MS analysis results from the mascot server showed that the $49.8 \mathrm{kDa}$ pili protein is S. flexneri similar to the flagellin protein of S. flexneri 1235-66 (ID 16H2T2). The results of antigenicity analysis and epitope mapping showed that areas of protein that has the most potential and antigenic epitopes are the regions 98-111 and 263-290 with the amino acid sequences, QSSTGTNSQSDLDS (Q-S) and DTTITKAETKTVTKNQVVDTPVTTDAAK $(D-K)$. The results of the molecular docking interaction test between the peptide and the B-cell receptor have a low binding energy. Peptide $Q$-S and peptide $\mathrm{D}-\mathrm{K}$ antigens are hemagglutinin molecules because they can agglutinate erythrocytes. The immune response between peptide antigens and anti-peptide antibodies can react based on color gradations in the dotblot method.

Conclusion: The amino acid sequences $\mathrm{Q}-\mathrm{S}$ and $\mathrm{D}-\mathrm{K}$ are potentially antigenic epitopes. These peptides can be used to develop candidates for shigellosis vaccine.
\end{abstract}

Key words: Shigella flexneri, pili protein, antigenic, epitope

\section{INTRODUCTION}

Shigellosis is an acute intestinal infection. The symptoms can range from mild diarrhea to severe inflammation. The characterization of bacillary dysentery is stomach cramps, fever, bloody stools, and mucus, especially in toddlers., Infection occurs globally, and in all people of all ages, endemic diseases occur in children aged 1-4 years, especially those living in low- and middle- income areas. ${ }^{3}$
Research conducted by Sumarno et al. ${ }^{4}$ shows that in pili Shigella dysenteriae contains a molecular weight hemagglutinin protein of 49.8 kilodalton ( $\mathrm{kDa}$ ) adhesin protein. Besides, other proteins are found $7.9 \mathrm{kDa}$ subunit protein, which is an antihemagglutinin. Both of these proteins are adhesin molecules in mice enterocytes. The results also revealed that $S$. flexneri, $S$. sonnei and S. boydii were also found to have pili proteins with molecular weights of $49.8 \mathrm{kDa}$ and $7.9 \mathrm{kDa} .^{5}$ 
The type and function of the protein S. flexneri $49.8 \mathrm{kDa}$ are still unknown. We had to analyze amino acid sequences of the $49.8 \mathrm{kDa}$ pili protein type from S. flexneri. Several studies have carried out secondary analysis and identification of epitopes in adhesin proteins as vaccine candidates. Pore et al. ${ }^{6}$ conducted research on amino acid sequences on $34 \mathrm{kDa}$ protein S. flexneri before recombinant. The results showed that the $34 \mathrm{kDa}$ protein is an OMPA protein from S. flexneri. Sharma et al. ${ }^{7}$ performed an analysis of modeling prediction of epitopes on OMP protein $S$. flexneri 2a. Research with 3D structural modeling has also been carried out with a $38 \mathrm{kDa}$ protein model, which is the $\mathrm{OmpC}$ S. flexneri 3a protein. ${ }^{8}$ After determining the expectation of the type of protein and the epitope, it is easier to perform cloning to produce recombinant proteins. This study aimed to determine the amino acid sequence and identify antigenic epitopes from BM $49.8 \mathrm{kDa}$ pili protein S. flexneri, which we would like to use as candidates for shigellosis vaccine.

\section{MATERIALS AND METHODS}

\section{S. flexneri bacteria}

Our study is a descriptive study conducted in the laboratory for the identification and exploration of the $49.8 \mathrm{kDa}$ S. flexneri pili protein epitope, which is an adhesive molecule and has potential as a shigellosis vaccine candidate. Bacteria used in this study were S. flexneri. Bacteria were cultured in Mac Conkey, brain-heart broth and thiaproline carbonate glutamate (TCG) medium. ${ }^{9}$ The results of bacterial collection on TCG media were collected and then shaved using a pili cutter. The isolated pili were then electrophorized to monitor the weight molecular of $49.8 \mathrm{kDa}$ protein.

\section{Animal and antigenic peptides}

We used 10 male mice (Mus musculus) Balb/C 6-8 weeks old, which were obtained from Experimental Animal Laboratory, Faculty of Medicine, Universitas Brawijaya, Indonesia. We used an antigenic peptide chemically produced. We purchased the antigenic peptides through the Apical Scientific Sdn. Bhd (Malaysia) in the form of synthetic peptides.

Amino acid sequence, antigenicity identification and epitope mapping of 49,8 kDa pili protein S. flexneri

We processed an amino acid sequence using the in-gel digestion method and analyzed liquid chromatography dual mass spectrometry (LC-MS/MS). The amino acid analysis was obtained from Mascot Server ( Hyperlink). Analysis of the identified antigenic protein was carried out using the approach in silico bioinformatics with the Kolaskar and Tongaonkar Antigenicity software (http://www.iedb.org) with value threshold (threshold value) 1.0.10 Epitope Mapping using Linear Epitope Prediction Bepired with a threshold value (entry) 0.35 of IEDB. The structure of proteins with epitope regions was visualized by software Pyre and PyMOL. ${ }^{11,12}$ Visualization of 3D structures resulting from molecular docking between peptides and $B$-cell receptors (BCR) (PDB ID: 5IFH) used PyMol software (https://pymol.org/2/).
Production of serum antibody pili protein epitope $49.8 \mathrm{kDa}$. flexneri

We used 5 mice per epitope for antibody production. The dose for immunization of each epitope was $50 \mu \mathrm{g}$ in a volume of $100 \mu \mathrm{L}$. The epitope of pili protein $49.8 \mathrm{kDa}$ S. flexneri was emulsified with complete Freud's adjuvant (CFA), and then $100 \mu \mathrm{L}$ was injected intraperitoneally. Weekly boosts were performed using antigens emulsified with incomplete Freud's adjuvant (IFA) at the same dose. The blood was removed from the heart one week after the last booster. The blood was placed in a sterile tube and centrifuged at $10.000 \mathrm{rpm}$ for five minutes. Then the serum was collected for further examination.

\section{Hemagglutination test}

We used two epitopes in the form of synthetic peptides to test for hemagglutination, namely, QSSTGTNSQSDLDS (Q-S) and DTTITKAETKTVTKNQVVDTPVTTDAAK (D-K) as well as serum antibodies from synthetic peptides produced in mice.

Samples IgG diluted half a series in a well-contained microplate $V$ with a volume of $50 \mu \mathrm{L}$ each in their wells a dilution solution used in PBS pH 7.4. Furthermore, in each well, a synthetic peptide antigen of $50 \mu \mathrm{L}$. We then incubated in a water bath by shaking 60 times a minute at $37^{\circ} \mathrm{C}$ for half an hour. After our incubation period completed in each well, we added $50 \mathrm{~mL}$ of mice's blood cells to a concentration of $0.5 \%$. We read the results of the agglutination inhibition reaction after incubation at room temperature for $1 \mathrm{~h}$. As a negative control, hemagglutination inhibition reaction used pre-serum was employed. ${ }^{5,13}$

\section{Dot blot test}

We used two epitopes in the form of synthetic peptides to test for dot blot, namely, Q-S and D-K, as used in the hemagglutination test. The dot blot test with immersed the nitrocellulose membranes was in sterile $\mathrm{H}_{2} \mathrm{O}$ for 30 min the membrane, dripped with $50 \mu \mathrm{L}$ antigen (synthetic peptide), and incubated overnight at $4^{\circ} \mathrm{C}$. The membrane with primary antibodies was $50 \mu \mathrm{L}$, set for $2 \mathrm{~h}$ at room temperature. Secondary antibody was added with 1:500 dilutions in FFB solution, incubated at room temperature for $1 \mathrm{~h}$. Chromogen substrate was added and incubated at room temperature for $30 \mathrm{~min}$. We stopped the reaction by adding $\mathrm{H}_{2} \mathrm{O}$-positive. Quality results are seen on the basis of color gradations. ${ }^{13}$ This research has obtained a statement letter from the Ethics Commission of Universitas Brawijaya with letter number of 1192-KEP-UB.

\section{Statistical analysis}

No statistical analysis was used in this study.

\section{RESULTS}

\section{Characterization of pili $48.9 \mathrm{kDa}$ protein of S. flexneri}

Sodium dodecyl-sulfate polyacrylamide gel electrophoresis identified S. flexneri pili protein. Pili protein profiles were generated from the first to third cuts of pili proteins, as shown in (Figure 1). 


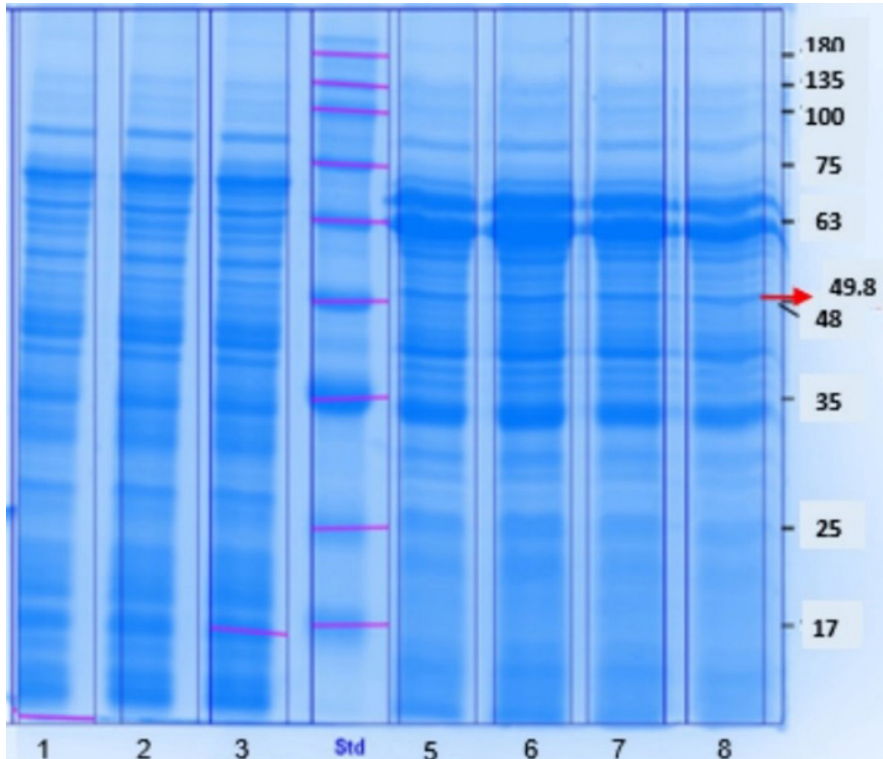

Figure 1. Electrophoresis results in a molecular weight of $49.8 \mathrm{kDa}$ pili protein Shigella flexneri. Pili protein profiles have various molecular weights. Columns 1, 2, and 3 results from the $3^{\text {rd }}$ pillar cut; 5 and 6 results from the $2^{\text {nd }}$ pili cut; 7 and 8 results from pili first cut
The analysis amino acid sequence of the protein of $49.8 \mathrm{kDa}$ pili S. flexneri

Analysis Mascot server showed that $49.8 \mathrm{kDa}$ protein S. flexneri has homology with flagellin protein belonging to $S$. flexneri 1235 66 (ID I6H2T2), with a query coverage of $18 \%$ and a molecular weight of $51.75 \mathrm{kDa}$ (Table 1).

\section{Antigenicity analysis and epitope mapping}

Analysis results from antigenicity of protein were done with Kolaskar and Tongaonkar antigenic software (Figure 2A and Table 2). Analysis of epitope mapping used the Bepired Linear Epitope Prediction software shows that some regions have epitopes shown in the yellow area in Figure 2B. Some of these epitopes have high scores as potential antigenic epitopes and areas adhesin molecules in the regions 98-111 and 263-290 with amino acid sequences Q-S and D-K (Table 3; highlight yellow).

\section{Modeling and visualization flagellin proteins}

Results of modeling protein structures with antigenic regions and areas of epitopes visualized by Pyrx and PyMO. Based on the visualization results, areas that have potential epitopes are in the order of 98-111 and 263-290. Known areas with antigenic potential at positions 276-283 are potential epitopes in regions 263-296 (Figure 2C, wire; red and yellow).
A

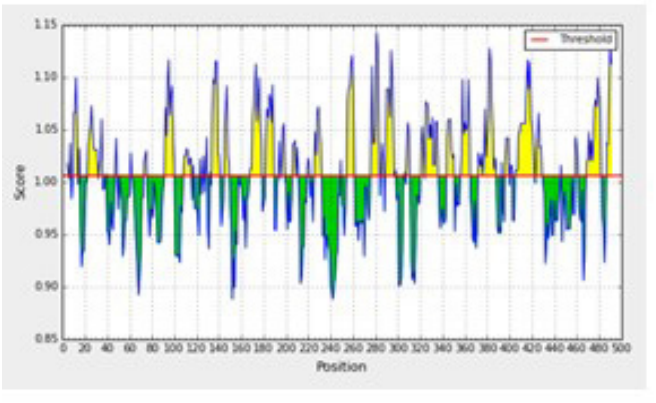

B

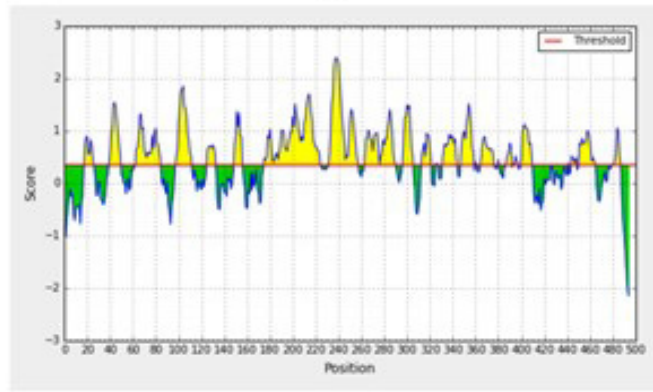

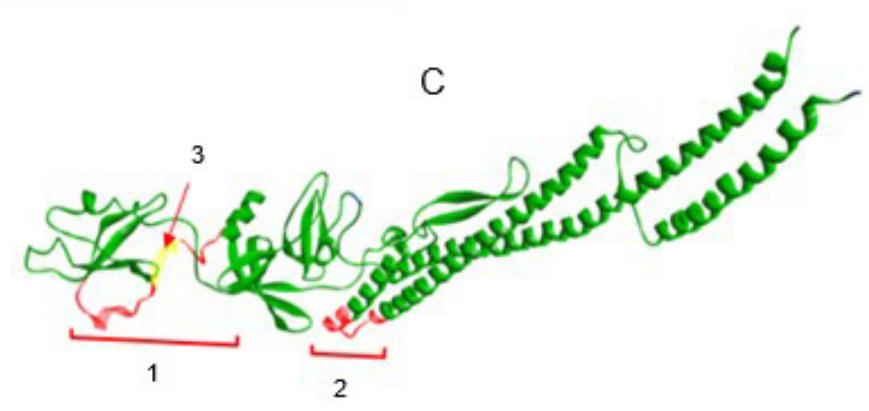

Figure 2. Analysis graph prediction of antigenicity, epitope mapping, and visualization of the Shigella flexneri flagellin protein. A) Antigenicity analysis (the yellow graph shows the lively antigenic areas, green shows antigenic negativity); B) Epitope mapping analysis (the yellow graph shows areas with potential epitopes, green indicates negative potential epitopes); C) Visualization of protein structures are characterized by (ribbon; green) with antigenic regions (line; yellow) and epitopes (wire; red). The potential epitope shows in areas C1 (98-111), C2 (263-290) (wire; red), and antigenic C3 (276-283) (line; yellow)

Table 1. Results of amino acid analysis of the $49.8 \mathrm{kDa}$ protein pili using the LC-MS/MS method on mascot server that has homology with the flagellin protein of Shigella flexneri

\begin{tabular}{lllll}
$\begin{array}{l}\text { Accession number } \\
\text { (uniprot/NCBI) }\end{array}$ & Protein & Query coverage (\%) & MW (Da) & Subcellular location \\
\hline I6H2T2/ EIQ75074.1 & Flagellin (Shigella flexneri 1235-66) & 18 & 51755 & Secreted \\
\hline
\end{tabular}

MW: Molecular weight, Da: Dalton, LC-MS/MS: Liquid chromatography dual mass spectrometry 


\section{Table 2. Analysis of antigenicity flagellin protein used Kolaskar and Tongaonkar software}

Protein identification

Flagellin (Shigella flexneri 1235-66) $\quad$ 16H2T2

\begin{tabular}{|c|c|c|c|c|}
\hline Accession number & Start & End & Peptide & Length \\
\hline & 23 & 31 & SSLSSAIER & 9 \\
\hline & 92 & 100 & VRELAVQSS & 9 \\
\hline & 109 & 115 & $\angle D S I Q A E$ & 7 \\
\hline & 134 & 141 & GVKVLAKD & 8 \\
\hline & 168 & 178 & LGLDSLSVQDS & 11 \\
\hline & 182 & 189 & TATVVGAG & 8 \\
\hline & 225 & 231 & GQHYVNI & 7 \\
\hline & 255 & 261 & GAVVIGA & 7 \\
\hline \multirow[t]{9}{*}{$16 \mathrm{H} 2 \mathrm{~T} 2$} & 276 & 283 & KNQVVDTP & 8 \\
\hline & 289 & 296 & $A K A L V D A G$ & 8 \\
\hline & 325 & 336 & $A L K V D D K Y Y A A D$ & 12 \\
\hline & 344 & 350 & AKTVAYT & 7 \\
\hline & 356 & 364 & SKEAAVQFG & 9 \\
\hline & 372 & 388 & IATVGGKQYLASSVKDH & 17 \\
\hline & 405 & 422 & ESPLAKIDAALAKVADLR & 18 \\
\hline & 424 & 429 & DLGAVQ & 6 \\
\hline & 469 & 482 & NILQQAGTSVLAQA & 14 \\
\hline
\end{tabular}

\section{Table 3. Identification of epitopes Shigella flexneri's flagellin protein used bepired linear epitope prediction software}

Protein Identification

Flagellin

(Shigella flexneri 1235-66)

\begin{tabular}{|c|c|c|c|c|}
\hline $\begin{array}{l}\text { Accession } \\
\text { number }\end{array}$ & Start & End & Peptide & Length \\
\hline \multirow{15}{*}{$16 \mathrm{H} 2 \mathrm{~T} 2$} & 232 & 257 & TDSTSTDPGKGNGMYKATIDPDTGAV & 26 \\
\hline & 98 & 111 & QSSTGTNSQSDLDS & 14 \\
\hline & 175 & 224 & $\begin{array}{l}\text { VQDSYKTTATVVGAGTYKDGVTITAPT } \\
\text { QGEIDAAVGGTAGEGKATVEFKD }\end{array}$ & 50 \\
\hline & 39 & 49 & NSAKDDAAGQA & 11 \\
\hline & 347 & 358 & VAYTDDKGVSKE & 12 \\
\hline & 296 & 305 & GVTGATDTNT & 10 \\
\hline & 263 & 290 & DTTITKAETKTVTKNQVVDTPVTTDAAK & 28 \\
\hline & 149 & 155 & GANDGET & 7 \\
\hline & 232 & 257 & TDSTSTDPGKGNGMYKATIDPDTGAV & 26 \\
\hline & 63 & 84 & QASRNANDGISIAQTTEGSLSE & 22 \\
\hline & 400 & 409 & ATAKTESPLA & 10 \\
\hline & 481 & 487 & QANQTTQ & 7 \\
\hline & 451 & 465 & SRIEDADYATEVSNM & 15 \\
\hline & 313 & 321 & EDKNGKVID & 9 \\
\hline & 331 & 343 & KYYAADYKDGKIT & 13 \\
\hline
\end{tabular}




\section{Docking molecular visualization and interaction}

Two peptides, which were considered as potential epitopes, were predicted for binding interactions between the peptide antigen and B-cell receptor. Molecular docking simulation was performed by interacting BCR-peptide (Figure 3 ).

\section{Antigenic peptides}

From the results of in silico analysis of $49.8 \mathrm{kDa}$ protein similar to flagellin protein, we selected two epitopes that were considered potential epitopes. The characteristics of these epitopes are presented in Table 4.

\section{Hemagglutination assay of epitope pili subunit proteins}

For the antigens' determining ability to agglutinate erythrocytes, we used the hemagglutination test (Figure 4A). The results display the function of anti-hemagglutination test. Antibodies can determine in inhibiting antigens' ability to agglutinate erythrocytes (Figure 4B).

\section{Immune response test using the dot blot method}

The dot-blot method results showed that the most effective immune response to peptide Q-S antigen-antibody occurred at $1 / 500$ and $10 \mathrm{ng}$ dilutions (Figure $5 \mathrm{~A}$ ). The most significant result of the immune response to peptide $D-K$ antigen-antibody occurred at $1 / 1000$ and $1 \mu \mathrm{g}$ dilutions (Figure 5B).

\section{DISCUSSION}

The results of the study using a bioinformatics approach to identify antigens in several serotypes of Shigella spp. shows the results of the identification of many peptides in Shigella

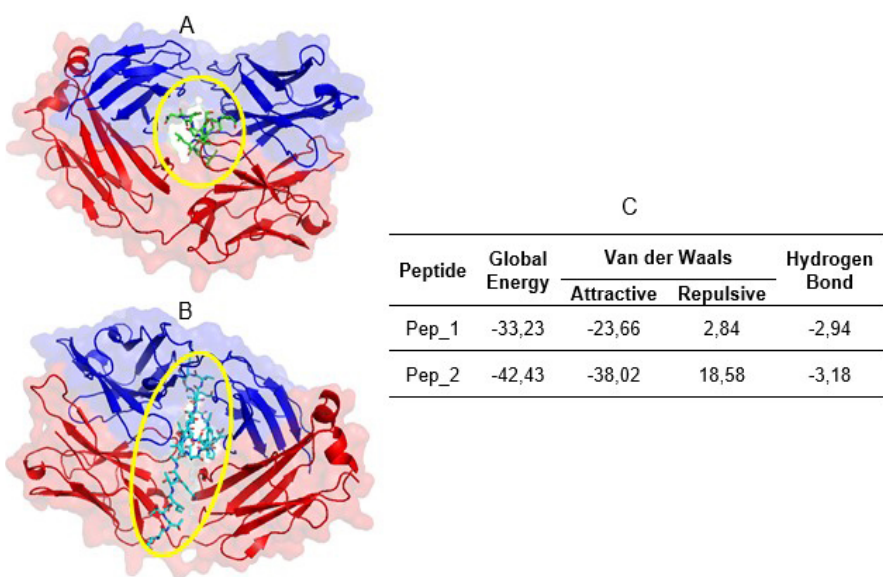

Figure 3. Visualization of $3 \mathrm{D}$ structure of the molecular docking analysis used PyMol software (https://pymol.org/2/). A. Pep_1 vs BCR; B. Pep_2 vs BCR; C. Value of binding energy peptide and BCR. The yellow circle indicates the location of the peptide when it binds to BCR

Pep_1: QSSTGTNSQSDLDS, Pep_2: DTTITKAETKTVTKNQVVDTPVTTDAAK BCR: B-cell receptor

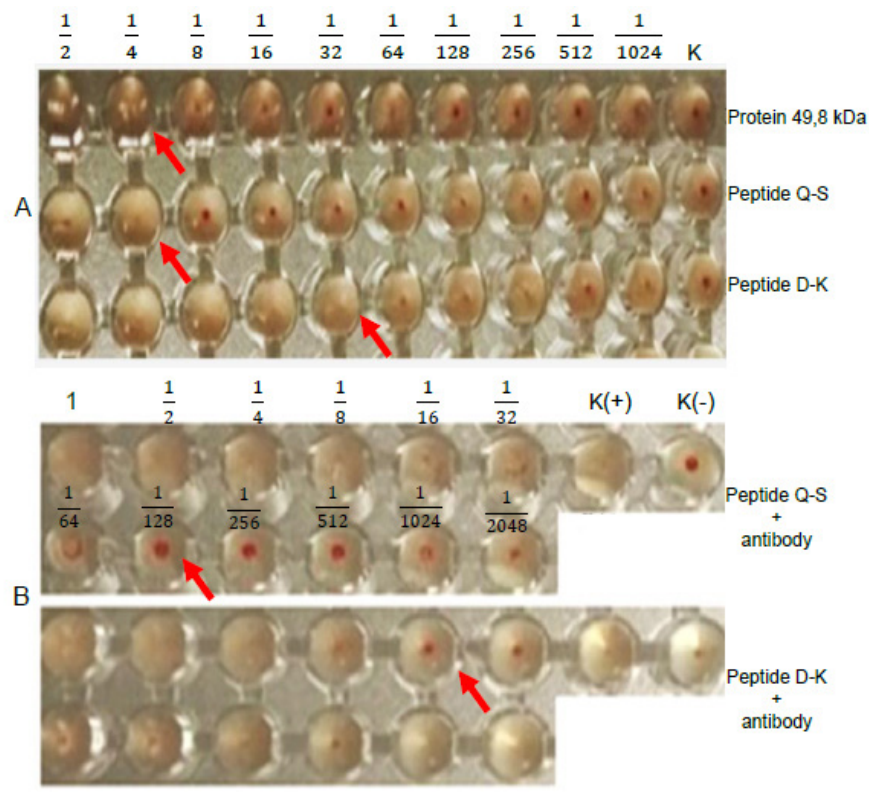

Figure 4. The results of hemagglutination and hemagglutination inhibition examination. A) The dilution used for the hemagglutination test of 49.8 kDa pili protein, Q-S peptides and D-K peptides are 1/2-1/1.024 (positive agglutination is indicated by a red arrow); B) The dilution used for the antihemagglutination test for $Q-S$ peptides and $D-K$ peptides is $1-1 / 2.048$ (positive antiagglutination is indicated by a red arrow)

Q-S: QSSTGTNSQSDLDS, D-K: DTTITKAETKTVTKNQVVDTPVTTDAAK, K: Control

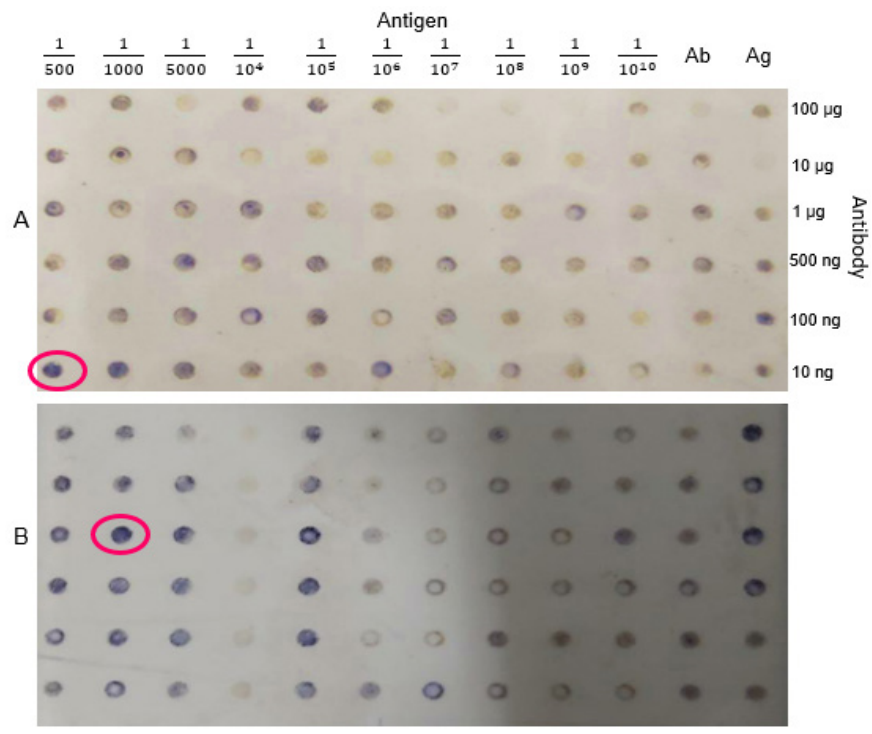

Figure 5. The results of the immune response antigen and antibody used the dot blot method. A) Q-S peptide; B) D-K peptide. More purplish blue indicates the stronger the immune response (red ring)

Q-S: QSSTGTNSQSDLDS, D-K: DTTITKAETKTVTKNQVVDTPVTTDAAK

Table 4. The characteristics of antigenic peptides determined by in silico analysis

\begin{tabular}{llllll} 
Name & Sequence of Peptide (Epitope) & Length & Formula & Purity & Solubility \\
\hline Peptide 1 & QSSTGTNSQSDLDS (Q-S) & 14 & $\mathrm{C}_{53} \mathrm{H}_{87} \mathrm{~N}_{17} \mathrm{O}_{29}$ & Crude & Soluble in water \\
\hline Peptide 2 & DTTITKAETKTVTKNQVVDTPVTTDAAK (D-K) & 28 & $\mathrm{C}_{126} \mathrm{H}_{218} \mathrm{~N}_{34} \mathrm{O}_{48}$ & Crude & Soluble in water \\
\hline
\end{tabular}


bacteria that are immunogenic. ${ }^{14}$ Bioinformatics serves to design vaccine candidates and can also be used to analyze the mechanism of bacterial resistance to drugs. ${ }^{15}$

The profile band of $S$. flexneri clearly displays that it has a molecular weight of $49.8 \mathrm{kDa}$ as an adhesion protein. This indicated that hemagglutinin and an adhesion protein in $S$. dysenteriae and S. flexneri have a molecular weight of 49.8 $\mathrm{kDa} .{ }^{4,5}$ Adhesins are proteins that can attach to cell receptors. This protein can also clump the enterocyte cells. ${ }^{9}$

Pili protein (49.8 $\mathrm{kDa}$ ) of S. flexneri analyzed with LC-MS/MS an in-gel digestion approach. Analysis Mascot server showed that $49.8 \mathrm{kDa}$ protein S. flexneri has homology with flagellin protein belonging to $S$. flexneri 1235-66 (ID 16H2T2), with a query coverage of $18 \%$ and a molecular weight of $51,75 \mathrm{kDa}$. Accession number $16 \mathrm{H} 2 \mathrm{~T} 2$, which is the ID of the uniprot database. We used database uniport because our study is about proteomics. However, the data is the same as the protein in NCBI database with accession number EIQ75074.1 (Table 1). Flagellin is a structural component that helps bacterial motility. This ability helps bacteria to avoid the immune system as well as harmful components in the host.16,17 As a virulent factor for Gram-negative pathogenic bacteria, flagellin is responsible for several functions such as movement, adhesion, and invasion. ${ }^{18}$ Shigella flagella (flash) has similarities to flagellin from Escherichia coli, Salmonella spp., and Proteus mirabilis. The results of the study indicate that Shigella is capable of forming flagella. ${ }^{19}$ The studies on Shigella genus revealed that 4 of 12 strains of $S$. boydii have fliC gene as protein-coding flagellin similar to S. flexneri. ${ }^{20}$

The analysis of protein antigenicity in silico with Kolaskar and Tongaonkar antigenicity software on flagellin proteins showed that the protein is very immunogenic because it has peptide regions that are potentially antigenic. These results follow Utami et al. ${ }^{9}$ research, which states that the $49.8 \mathrm{kDa}$ S. flexneri pili protein is an adhesin protein that can increase the intestinal immune response of mucosa. Results of analysis epitope mapping in silico using Bepired Linear Epitope Prediction software indicated that the protein flagellin epitopes are some regions. The immune system can recognize the epitopes following the yellow area in Figure 2B. After scoring, some epitopes were identified based on antigenic epitopes two, and the most potential is in the regions of 98-111 and 263-290 with the sequences of Q-S and D-K. A study has successfully identified the IpaC protein parts and the IpaD protein; $S$. flexneri $2 \mathrm{a}$, which are epitopes of that protein. ${ }^{21,22} 3 \mathrm{D}$ structural modeling can predict the presence of antigenic peptides or epitopes from the OMP proteins; S. flexneri 2a and S. flexneri 3a. ${ }^{7,8}$

Based on analysis visualization using Pymol software pointed out that the model of the structure of the flagellin protein with antigenic region peptides in the amino acid sequence $D-K$ appeared to have the same area as the antigenic region and the epitope location. The peptide is considered a potential epitope. Further analysis using software for adhesin prediction showed that the peptide Q-S is an adhesive region. These results support the hypothesis that receptors will recognize the peptide on the surface of the host cell. On the surface of the host cell, there are specific proteins called receptors. The bacterial adhesive can be glycoprotein or lipoprotein found in fimbriae or pili. ${ }^{23}$

We performed docking analysis on peptides with B-cell receptors or BCRs. Our molecular docking studies aimed to determine vaccine candidate peptides that have low binding energies. The docking results displayed that pep_1 and pep_2 had a low average binding energy, which allows the initiation of a biological response, namely, activation of BCR capable of triggering an immune response in B-cells to produce specific antibodies. The PatchDock and FireDock programs are significantly faster and perform slightly better than other programs because they can overcome protein flexibility. Docking applications can be used for polypharmacology prediction, drug use, fishing targets, and profiling. ${ }^{24-26}$

We ordered the antigenic peptides for the in silico analysis in the form of synthetic peptides. The pure peptide was used as this is a preliminary study to prove our peptides as potential ingredients of vaccine candidates. So that, we could use protein with higher purity later, if our current results are promising. The amino acid sequences we used are soluble in water, making them easy to dissolve in solvents such as PBS (Table 4). We injected peptides into experimental animals for the production of serum antibodies. Our immunization was administered intraperitoneally using CFA and IFA to facilitate peptide's dissolution in the blood.

Our hemagglutination analyses included two antigenic peptides and serum antibodies from both. Antigenic peptides to test for hemagglutination were, namely, Q-S and D-K. The results of the hemagglutination test showed a difference in erythrocyte agglutination that could be observed from $Q-S$ and $D-K$ peptides. $Q-S$ peptide antigen is capable of agglutination at $1 / 4$ titer. Meanwhile, D-K peptide exhibited agglutination at 1/32 titer. These results proved that $\mathrm{Q}-\mathrm{S}$ and $\mathrm{D}-\mathrm{K}$ peptide antigen can bind to erythrocytes or known as hemagglutinin molecules. The peptide antigen used is the epitope of S. flexneri bacteria's pili protein with a molecular weight of $49.8 \mathrm{kDa}$, which is an adhesive protein. ${ }^{9}$ The anti-hemagglutinin test carried out used serum $Q-S$ peptide antibodies against $Q-S$ peptides, and $D-K$ peptide antibodies against D-K peptides. Q-S peptide antibody can inhibit $Q-S$ peptide antigen starting at 1/128 dilution. While $\mathrm{D}-\mathrm{K}$ peptide antibody could inhibit $\mathrm{D}-\mathrm{K}$ peptide antigen starting from 1/16 dilution. The sediment that occurs at the bottom of the well demonstrated presence of antihemagglutination. ${ }^{13}$

Process immunoblotting analysis used dot blotting. ${ }^{27}$ The dot blot test also uses the same two antigenic peptides and antibodies as in the hemagglutination test. Antigen-antibody reaction of $\mathrm{Q}-\mathrm{S}$ peptide and $\mathrm{D}-\mathrm{K}$ peptide antibodies by reacting to $\mathrm{Q}-\mathrm{S}$ peptides and D-K used, the dot blot method. The purplish-blue marked positive dot blot test results between $Q-S$ peptide antibody with Q-S peptide and D-K peptide antibody with D-K peptide. The results of the research using the dot blot method in this study follow the results of previous studies, namely that the synthesis of peptide $\mathrm{A}-\mathrm{K}$ antigen from the $49.8 \mathrm{kDa}$ S. flexneri pili protein can conduct an immune response with its serum antibodies. ${ }^{13}$ 
The reaction of the peptide with the antibody will cause a color gradation of the dot blot results and quantitatively use Corel photo paint. ${ }^{28}$ Our study did not adhesion test between antigen with enterocyte cells as a confirmation method to prove that an antigen is an adhesion molecule, as did Milliana et al. ${ }^{29}$, who proved that the $28 \mathrm{kDa}$ OMP of $S$. flexneri is an adhesion protein.

\section{CONCLUSION}

Pili protein $49.8 \mathrm{kDa}$ has potential antigenic epitopes, namely, $\mathrm{Q}-\mathrm{S}$ and $\mathrm{D}-\mathrm{K}$ peptide. Both peptides are hemagglutinin molecules.

\section{ACKNOWLEDGMENTS}

The authors would like to thank Suci Megasari Central of Biomedik Laboratory, Faculty of Medicine, Brawijaya University to help analysis of the work.

\section{Ethics}

Ethics Committee Approval: This research has obtained a statement letter from the Ethics Commission of Universitas Brawijaya with letter number: 1192-KEP-UB.

Informed Consent: Not necessary.

Peer-review: Externally peer-reviewed.

\section{Authorship Contributions}

Surgical and Medical Practices: K.A., A.T.E., Concept: S.R.P., Design: S.P., Data Collection or Processing: K.A., Analysis or Interpretation: K.A., A.T.E., Literature Search: K.A., Writing: K.A. Conflict of Interest: No conflict of interest was declared by the authors.

Financial Disclosure: The authors declared that this study received no financial support.

\section{REFERENCES}

1. Niyogi SK. Shigellosis. J Microbiol. 2005;43:133-143.

2. Schroeder GN, Hilbi H. Molecular pathogenesis of Shigella spp.: controlling host cell signaling, invasion, and death by type III secretion. Clin Microbiol Rev. 2008;21:134-156.

3. Kotloff KL, Riddle MS, Platts-Mills JA, Pavlinac P, Zaidi AKM. Shigellosis. Lancet. 2018;391:801-812.

4. Sumarno RP, Avanita AS, Winarsih S, Hidayat S, Nurhidayati DY. Haemagglutination of Shigella dysenteriae subunit pili protein with an anti-haemagglutination of Shigella dysenteriae subunit pili protein as a molecule adhesin in mouse enterocytes. Afr J Med Res. 2015;9:781-787.

5. Anam K, Nurdiana, Herowati TE, Suyuti H, Sumarno RP. Cross immunity among pili sub-unit hemagglutinin and pili sub-unit anti hemagglutinin proteins of Shigella spp. ljppr. Human. 2016;7:19-30.

6. Pore D, Mahata N, Pal A, Chakrabarti MK. Outer membrane protein A (OmpA) of Shigella flexneri 2a, induces protective immune response in a mouse model. PLoS One. 2011;6:e22663.

7. Sharma D, Patel S, Padh H, Desai P. Immunoinformatic identification of potential epitopes against shigellosis. Int J Pept Res Ther. 2016;22:481495.
8. Jarząb A, Witkowska D, Ziomek E, Dąbrowska A, Szewczuk Z, Gamian A. Shigella flexneri 3a outer membrane protein $C$ epitope is recognized by human umbilical cord sera and associated with protective activity. PLoS One. 2013;8:e70539.

9. Utami WJ, Wiwik A, Winarsih S, Suyuti H, and Sumarno RP. The fermented horse milk can as an immune stimulant pili sub units of $S$. flexneri protein conjugated with CTB in mice. ASPS. 2017;1:30-37.

10. Gomase VS, Changbhale SS, Chitlange NR, Sherkhane AS. Prediction of antigenic epitopes from Tityus serrulatus venom allergen 5: an aid to antitoxin vaccines. J Toxicol Res. 2012;2:20-24.

11. Armiyanti Y, Arifianto RP, Nurmariana E, Senjarini K, Widodo, Fitri LE, Sarjdono TW. Identification of antigenic proteins from salivary glands of female Anopheles maculatus by proteomic analysis. Asian Pac J Trop Biomed. 2016;6:930-936.

12. Mufida DC, Handono K, Sumarno RP, Santoso S. Identification of hemagglutinin protein from Streptococcus pneumoniae pili as a vaccine candidate by proteomic analysis. Turk J Immunol. 2018;6:8-15.

13. Sumarno, Anam K, Utami YW, Nurhidayati Y, Winarsih S, Suyuti $H$. The response of anti-peptide serum antibodies ATLGATLNRLDFNVNNK derived from $S$. flexneri protein sub-unit pili toward activity the hemagglutination and protection from leaking solution enterocyte in mice. Arch Immunol Allergy. 2019;2:49-57.

14. Pahil S, Taneja N, Ansari HR, Raghava GPS. In silico analysis to identify vaccine candidates common to multiple serotypes of Shigella and evaluation of their immunogenicity. PLoS One. 2017;12:e0180505.

15. Koçak E, Özkul C. Comparative proteomic analysis of Escherichia coli under ofloxacin stress. Turk J Pharm Sci. 2021;18:133-139.

16. Smith KD, Andersen-Nissen E, Hayashi F, Strobe K, Bergman MA, Barrett SL, Cookson BT, Aderem A. Toll-like receptor 5 recognizes a conserved site on flagellin required for protofilament formation and bacterial motility. Nat Immunol. 2003;4:1247-1253. Erratum in: Nat Immunol. 2004;5:451.

17. Bagheri M, Zahmatkesh A. Evolution and species-specific conservation of toll-like receptors in terrestrial vertebrates. Int Rev Immunol. 2018;37:217-228.

18. Khani MH, Bagheri M. Introducing a cost-effective method for purification of bioactive flagellin from several flagellated gram-negative bacteria. Protein Expr Purif. 2019;155:48-53.

19. Girón JA. Expression of flagella and motility by Shigella. Mol Microbiol. 1995;18:63-75.

20. Tominaga A, Mahmoud MA, Al Mamun AA, Mukaihara T. Characterization of cryptic flagellin genes in Shigella boydii and Shigella dysenteriae. Genes Genet Syst. 2001;76:111-120.

21. Turbyfill KR, Joseph SW, Oaks EV. Recognition of three epitopic regions on invasion plasmid antigen $\mathrm{C}$ by immune sera of rhesus monkeys infected with Shigella flexneri 2a. Infect Immun. 1995;63:3927-3935.

22. Turbyfill KR, Mertz JA, Mallett CP, Oaks EV. Identification of epitope and surface-exposed domains of Shigella flexneri invasion plasmid antigen $D$ (IpaD). Infect Immun. 1998;66:1999-2006.

23. Tortora GJ, Funke R, Case CL. Microbiology an introduction. $10^{\text {th }}$ ed. San Francisco, CA: Pearson Benjamin Cummings; 2010.

24. Andrusier N, Nussinov R, Wolfson HJ. FireDock: fast interaction refinement in molecular docking. Proteins. 2007;69:139-159. 
25. Mashiach E, Schneidman-Duhovny D, Andrusier N, Nussinov R, Wolfson HJ. FireDock: a web server for fast interaction refinement in molecular docking. Nucleic Acids Res. 2008;36(Web Server issue):W229-W232.

26. Pinzi L, Rastelli G. Molecular docking: shifting paradigms in drug discovery. Int J Mol Sci. 2019;20:4331.

27. Tian G, Tang F, Yang C, Zhang W, Bergquist J, Wang B, Mi J, Zhang J. Quantitative dot blot analysis (QDB), a versatile high throughput immunoblot method. Oncotarget. 2017;8:58553-58562.
28. Salah BMS, Kusworini H, Sumarno RP. Sensitivity and specificity of OMP Acinetobacter baumannii antigen dot blot to detect secretory-lgA in the urine of patients with Acinetobacter baumannii infection. IOSR J Pharm Biol Sci. 2014;9:6-15.

29. Milliana A, Noorhamdani AS, Poeranto S, Handono K, Prawiro SR, Fitrianingsih AA, Rachma LN. Antibodies againt Shigella flexneri adhesion molecule outer membrane protein (OMP) can cross-react with OMPs of some Shigella species. Trop J Pharm Res. 2017;16:255-261. 